\title{
Nacionalismo telúrico y discurso plástico. La Revista Nativa y su propuesta estético-política en la Argentina de los albores de los 30
}

\author{
Paula Cecilia Hrycyk ${ }^{1}$
}

Resúmen: El tema de este trabajo se concentra en analizar la manera en la que un grupo de nacionalistas argentinos, nucleados en torno a la Revista Nativa, se incorporan al debate sobre la idea de "lo nacional" en el arte a fines de la década del 20. Nativa, es una publicación cultural mensual que se presenta a sí misma como autoridad en nacionalismo y tradición, como una "empresa patriótica". Se ubica en el campo editorial como epicentro gráfico desde el que expresa una clara preocupación por marcar el ritmo del devenir artístico nacional como parte de un proyecto global que apela a reafirmar las bases de una cosmovisión esencialista de la argentinidad. La dureza de la crítica que profiere a la innovación y a la vanguardia en el Argentina, se explican en el carácter misional que se atribuye la publicación y el rol central que asigna a la injerencia del arte y la cultura en la consolidación de los cimientos de una identidad nacional criolla. La selección de imágenes está, aparentemente, ligada a la búsqueda de recuperar una tradición anterior a la impuesta por el ideario liberal que se pretende combatir. En esta operación de asociación de política y arte, aparece la naturaleza como elemento clave a la hora de redefinir un mito de orígenes. Nos ocuparemos de reflexionar sobre la promoción de los artistas y el arte "nacionalista" como instrumentos o soportes paran mostrar a los ciudadanos y al resto del mundo de qué se trata ser argentino.

Abstract: The topic of this article concentrates in the analysis of the way a group of Argentine nationalists, from Revista Nativa, intervene in the debate about the idea of nation in the art field by the end of the 20s. Nativa, is a cultural monthly publication that

\footnotetext{
${ }^{1}$ Jefa de Trabajos prácticos, problemas mundiales contemporáneos, Facultad de Filosofía y Letras - Historia, Universidad de Buenos Aires. Dirección: P. Gaspar Campos, 480, C.A.B.A. Correo electrónico: phrycyk@yahoo.com.ar, phrycyk@gmail.com.
}

Revista Eletrônica da ANPHLAC, n.11, p. 76-104, jul./dez. 2011. http://revista.anphlac.org.br/index.php/revista 
introduces itself as the printed epicenter from which emanates the preoccupation to delineate an artistic path that is part of a global project oriented to reaffirm an essentialist perspective of the Argentinehood. Its harsh criticism of the innovation and avant-guardism can be explained in the missionary character of the basis of the creole national identity. The selection of images is, apparently, connected to the search to recuperate traditions and a folklore that existed before the imposition of a liberal agenda that these nationalists were fighting against. They propose an association between politics and art in which nature appears to be the key element to understand and redefine the myth of origins. We will analyze the way they promote a nationalistic art and artists as instruments to show local citizens and the rest of the world what it means to be an Argentine.

Palabras clave: identidad nacional, artes plásticas, comunidades discursivas, nacionalismo telúrico.

Key words: national identity - visual arts - speech communities - folkloric nationalism

El tema de este trabajo se concentra en analizar la manera en la que un grupo de nacionalistas argentinos, nucleados en torno a la Revista Nativa, se incorporan al debate sobre la idea de "lo nacional" en el arte a fines de la década del 20, contribuyendo a aquella discusión colectiva acerca de la historia nacional que cobrará distintos impulsos entre el Centenario y el levantamiento del General Uriburu. ${ }^{2}$ La necesidad de dar homogeneidad a un conjunto de individuos, que si tenían algo en común es que provenían de naciones y culturas dispares y eran portadores de identidades afincadas en dichas diferencias, ocupa la reflexión de los intelectuales argentinos desde la independencia en adelante. El cosmopolitismo, los efectos "contaminantes" de la inmigración y la creciente apertura y democratización de las prácticas políticas, culturales y sociales, que en la Argentina habrían alcanzado su máxima expresión en las elecciones presidenciales de 1916, forma parte de

\footnotetext{
${ }^{2}$ En este lapso (1910-1930) Argentina fue escenario de una serie de ensayos políticos en los que el futuro democrático del país parecía prometedor. La Ley Saenz Peña de 1912 inauguraba la posibilidad de una participación política universal (masculina) y secreta que se vería concretada en 1916 con la elección del primer presidente de la nación, Hipólito Yrigoyen, que no provenía de un partido de los sectores conservadores. Sin embargo, este oportunidad de los sectores medios de encontrarse representados a nivel nacional se vio pronto obturada por el acaecimiento del golpe de estado de 1930, liderado por el General Uriburu.
}

Revista Eletrônica da ANPHLAC, n.11, p. 76-104, jul./dez. 2011. http://revista.anphlac.org.br/index.php/revista 
una serie de procesos de cambio que son tomados como signos de una crisis a nivel identitario por el nacionalismo cultural y que conducen a una nueva puesta en debate de lo nacional orientada a repensar un mito fundante que aportase una nueva organicidad al sentir patrio. ${ }^{3}$ A partir de la mirada de sus intelectuales intentamos rastrear de qué manera se plasma en imágenes y discursos la aspiración de refundar un mito de orígenes nacional en clave tradicionalista y esencialista, las estrategias de readaptación de los bienes simbólicos e instrumentales, el papel atribuido a la plástica en la construcción de las representaciones de orden, entre otras cosas.

En esta oportunidad nos ocuparemos de la revista Nativa, publicación cultural que expresa una clara preocupación por marcar el ritmo del devenir artístico nacional como parte de un proyecto global que apela a reafirmar las bases de una cosmovisión esencialista de la argentinidad. Fundada en 1924 y en prensa por 40 años, esta publicación mensual se presenta a sí misma como autoridad en nacionalismo y tradición, como una "empresa patriótica" y se ubica en el campo editorial como epicentro gráfico desde el que se difunden, en un lenguaje accesible y cotidiano, las ideas de los intelectuales del Centenario. En, prácticamente, todos los números de la revista se reiteran alternadamente recuadros que ofician de una suerte de publicidad del objeto y la obra de este emprendimiento editorial. Uno de los más frecuentes orientado a marcar la singularidad de Nativa en el campo editorial y, por qué no, intelectual, es: "En nuestro inmenso territorio de 3.000 .000 de kilómetros cuadrados, y sobre más de 10.000 publicaciones que se editan en el mismo, sólo una de ellas realiza verdadera obra argentina: NATIVA”. O “Adquiera usted NATIVA para su hogar; pronto se convencerá de que es la revista más sana e instructiva lectura. Recuerde de sus niños... (sic)". ${ }^{4}$

Otra de sus singularidades es que se ofrece como un escenario puramente federal en el que desfilan personajes del mundo de la cultura de las provincias, en el que se pondera

\footnotetext{
${ }^{3}$ En un tradicional trabajo sobre el desarrollo de las ideas en la Argentina, J. L. Romero da cuenta de la manera en que este nacionalismo va adquiriendo fuerza política a partir de su reacción contra el proceso de cambio que se recrudece a principios del siglo XX y las consecuencias indirectas de la modernización: el avance de la inmigración, la "plebeyización" de la política, el sacudimiento del orden social tradicional y la consecuente subversión de valores. ROMERO, J. L. El desarrollo de las ideas en la sociedad argentina del siglo XX. Buenos Aires: AZ editores, 1998. p. 169-171.

${ }^{4}$ En Nativa, n. 88, nov. 1930.
}

Revista Eletrônica da ANPHLAC, n.11, p. 76-104, jul./dez. 2011. http://revista.anphlac.org.br/index.php/revista 
una poética y una estética que recupera los valores de la patria entera. ${ }^{5}$ Esto mismo se observa en la organización temática de cada número, que generalmente versa sobre una región del país, sus instituciones culturales, arte y personajes de relevancia; además, se plasma en dos de las secciones donde aparece más claramente la postura editorial de la revista: "Arte Argentino" — generalmente escrita por su director Julio Diaz Usandivaras ${ }^{6}$ — y "Siluetas Nacionalistas" — a cargo de algún escritor invitado. La selección plástica es parte de la temática y en la sección de Arte Argentino se analiza la obra del pintor del cuadro de la portada, cuya obra se promociona como ejemplo de tradición y nacionalismo argentino. En esta sección, además, se filtran observaciones respecto a la relación con el arte de vanguardia y la situación del campo artístico, alusiones que son siempre indirectas ya que nunca merecen un artículo dedicado a ellas. A raíz de una nota sobre la pintura de Casaza, Pascual Ayllón, quien ocasionalmente colabora con la sección Arte Argentino señala respecto al arte de vanguardia: "[...] casos como este nos consuelan de esa pintura bárbara de brochazos $\mathbf{y}$ borrones que jamás se armonizan [...] únicamente los desconciertos del sentido han podido dar actualidad a esa pintura desconcertante y fea."7 Meses después en la misma sección Usandivaras agrega:

[...] los desorientados (para algunos "los nuevos pintores") ( $i \ldots ?)[\ldots]$ el grupo de la mentira y el capricho. Porque si el arte es verdad, si el arte es el más fiel reflejo de la realidad, entonces lógicamente, lo que esos hacen no es arte [...] este mamarracho de ahora, que proclama "pintura" ese grupo llamado vanguardista. ${ }^{8}$

Aquí advertimos que esta crítica sobre lo que se puede aceptar como arte argentino en nuestro campo artístico aparece como inseparable de la insistencia en el carácter

\footnotetext{
${ }^{5}$ Entre otras cosas, uno de los elementos más interesantes de esta revista es que no sólo se propone como una revista de alcance nacional sino que ofrece una propuesta plástica muy abarcativa del acontecer en las provincias y, como las cartas de lectores parecerían confirmar, alcanza a un amplio público de una gran cantidad de provincias. Si bien la revista es publicada en Buenos Aires, son pocas las marcas que remiten a dicho origen en pos de la insistencia en su carácter federal.

${ }^{6}$ El director y fundador de Nativa, Julio Diaz Usandivaras, proviene de una familia cordobesa de origen patricio, pero está radicado en Buenos Aires desde los 20s.

${ }^{7}$ Cabe observar que aquí ya aparece claramente la asociación de lo bárbaro con lo europeo. Inversión de la dicotomía liberal de civilización y barbarie sobre la que profundizaremos más adelante. Ayllón, P. Arte Argentino. Nativa, n. 73, enero 1930. Las negritas fueron agregadas.

${ }^{8}$ USANDIVARAS, J. Arte Argentino. Nativa, n. 82, oct. 1930. Las negritas fueron agregadas.
}

Revista Eletrônica da ANPHLAC, n.11, p. 76-104, jul./dez. 2011. http://revista.anphlac.org.br/index.php/revista 
primordialmente misional de la responsabilidad del artista. En artículo denominado "Nativa y los pintores", el editor plantea una distinción entre los artistas patrióticos y aquellos a los que denosta por "comerciantes" — es decir, los que no ponen en primer plano el carácter pedagógico de su obra donando una obra a la galería de la revista. Veamos las siguientes citas alusivas a esta distinción entre artistas y comerciantes así como al compromiso patrio que subyace a dicha diferencia:

[...] existen pintores argentinos a quienes se les ha reproducido 4,5 obras $[\ldots]$ sin que jamás hayan tenido la gentileza de destinar uno de sus cuadros a la galería que $[\ldots]$ se viene formando en esta casa del criollismo bien entendido y bien cumplido. [...] Deberá saberse que nadie más que el mismo artista le conviene figurar con una de sus obras en la galería de NATIVA, ya que esta se preocupa

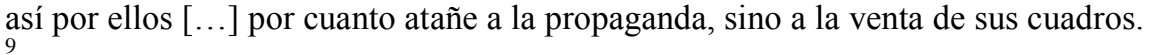

El artista debe ser artista hasta en la necesidad; de lo contrario no es artista, es comerciante. ${ }^{10}$

La dureza de la crítica sólo se explica en el carácter misional que se atribuye la publicación y el rol central que asigna a la injerencia del arte y la cultura en la consolidación de los cimientos de una identidad nacional criolla. Si bien no hay citas expresas a autores de referencia, esta preocupación por la misión del intelectual/artista definida como la contracara de una empresa comercial y/o cosmopolita solo se distancia geográficamente de las preocupaciones que aquejaban a los intelectuales europeos en el finde-siglo. Aún más, nos recuerdan a las intervenciones de intelectuales europeos, ampliamente difundidos en la Argentina de principios de siglo - como Oswald Spengler, Charles Maurrás o Jaques Maritain, entre otros - quienes atacaban el avance del "espíritu comercial" en su rebelión contra la sensación de alienación producida por el crecimiento de las metrópolis, el desarrollo de la industrialización y predominio del cosmopolitismo por sobre las tradiciones nacionales. Sin embargo, el caso de esta revista es distintivo en tanto brinda una plataforma para un fenómeno que tiene sus ribetes propios: la necesidad de seleccionar un conjunto de prácticas, costumbres y tradiciones que pudieran ser propuestos como una tradición nacional unificada en una nación que se caracterizaba por una historia

\footnotetext{
${ }^{9}$ Id., Nativa y los pintores. Nativa, n. 55, jul. 1928.

${ }^{10}$ Id., Arte argentino. Nativa, n. 57, sept. 1928.
}

Revista Eletrônica da ANPHLAC, n.11, p. 76-104, jul./dez. 2011. http://revista.anphlac.org.br/index.php/revista 
de hetorogenidad cultural y dificultades de unificación político-institucional. Por qué no pensar, entonces, que lo que Nativa realiza en el campo de la plástica sería un ejercicio similar al de Lugones en la literatura con la recuperación del Martín Fierro como poema nacional. $^{11}$

Esta publicación en tanto objeto de estudio ofrece, por un lado, un profuso acervo plástico al que difunde como estética de lo nacional y por el otro, una manera de insertarse en el campo cultural y editorial como autoridad a la hora de definir quienes actúan patrióticamente y quienes no, como si se atribuyeran la función de constituirse en adalides del programa cultural de aquello que en la historiografía argentina se denomina "nacionalismo tradicionalista telúrico"; Nacionalismo que se coloca en línea de continuidad con la Generación del Centenario ${ }^{12}$ en la denuncia de los primeros síntomas significativos de la crisis del proyecto de la Generación del 80 y que apela a la asimilación cultural de las masas de inmigrantes. ${ }^{13}$ Tradicional y telúrico porque la diagramación entera de la revista, la crítica de arte, su poesía y gráfica se inspiran en la “[...] exaltación del terruño, descripciones del paisaje y las costumbres lugareñas, oposición al cosmopolitismo [y a...] la relajación de normas éticas $[\ldots]{ }^{\prime} .{ }^{14}$

El espacio de discusión cultural y política que se observa en el ámbito del mercado editorial de la Argentina, como señala Miguel Ángel Muñoz, nos aporta ricas perspectivas

\footnotetext{
${ }^{11}$ En El Payador, Lugones presenta al, hasta entonces denostado, escrito de José Hernández como el poema épico por antonomasia de la Argentina dando así al gaucho el carácter de argentino "nativo" y contrafigura del inmigrante que contamina la vida cultural argentina con trayendo prácticas cosmopolitas. Véase: Lugones, L. El Payador, 1913.

${ }^{12}$ Esta es una generación está compuesta por una serie de intelectuales que hacia el Centenario se ocupan de reflexionar y forjar un universo de representaciones comunes. Para diferenciarse de la generación anterior, la del 80, se apartaran del modelo institucional liberal promovido por éstos. Se sumergirán en una discusión en la que la sanción de la Ley Saenz Peña y la creciente inmigración marcarán el rumbo de una clara polarización en la toma de posiciones. De esta polarización se bifurcarán dos modos diferentes de pensar lo nacional. Por un lado, están aquellas reflexiones más globales que piensan en la construcción de una argentinidad; en otras palabras, en las maneras posibles de dar homogeneidad a las diferencias dentro del marco de la nación argentina. Por el otro, se observa el surgimiento de un nacionalismo en tanto corriente política. El primero suele ser definido como nacionalismo en sentido amplio y el segundo como nacionalismo en sentido estricto. Véase: DEVOTO, F. Nacionalismo, fascismo y tradicionalismo en la Argentina moderna. Una historia. Buenos Aires: Siglo XXI Editores, 2002.

${ }^{13}$ FALCÓN, R., "Militantes, intelectuales e ideas políticas", en Idem (director), Nueva Historia Argentina. Democracia, Conflicto Social y renovación de ideas. (1916-1930).Buenos Aires, Editorial Sudamericana, 2000. p. 325

${ }^{14}$ FALCÓN, op. cit., p. 331.
}

Revista Eletrônica da ANPHLAC, n.11, p. 76-104, jul./dez. 2011. http://revista.anphlac.org.br/index.php/revista 
sobre el debate sobre la identidad nacional y el papel del arte en su consolidación en torno las décadas de 1910 y $1920 .{ }^{15}$ Uno de los elementos más sobresalientes es el importante papel que adquiere la prensa en tanto soporte físico de este debate. Otro de los aspectos fundamentales tiene que ver con las características que asume el campo artístico argentino en estos años, las relaciones de fuerza y las disputas por la legitimidad de los diferentes grupos. Entre fines de la década del 20 y principios del 30 quedan establecidos los cimientos de la institución arte, aparecen las primeras vanguardias, se complejiza el debate sobre qué es el arte nacional y cuál es el papel de los artistas a raíz de las preocupaciones contemporáneas que permean al campo artístico. Estas comprenden temas que versan sobre los alcances de la modernidad, las transformaciones en las prácticas sociales y culturales locales, el impacto de la revolución soviética, el avance del fascismo en Italia, la Guerra Civil española, entre otros. ${ }^{16} \mathrm{Si}$ tomamos las editoriales, la selección iconográfica y las observaciones de lo que admite como "verdadero arte argentino", podemos alcanzar una primera impresión de la incursión de Nativa al interior de estas discusiones que puede llevarnos a concluir, quizás apresuradamente, que lo que esta ofrece son muestras propias de un nacionalismo ingenuo. Perspectiva ésta que nos haría desistir de cualquier intento que superase la dimensión descriptiva de la revista. Sin embargo, una mirada de largo plazo a los alcances del mensaje que contribuye a difundir nos hace pensar que éste ha calado en la sociedad argentina a tal punto que ha pasado a conformar parte del sentido común. Elemento no menor y que habilita un estudio que requiere mayor profundización que una descripción. Con el objeto de llevar a cabo esta empresa hemos tomado en préstamo una serie de conceptos y nociones teóricas de la sociología, la semiología y la historia intelectual que pondremos al servicio de desentrañar le complejidad que yace detrás de la aparente ingenuidad discursiva.

15 MUÑOZ, M. A. Un campo para el arte argentino. Modernidad artística y nacionalismo en torno al Centenario. In: WECHSLER, D. Desde la otra vereda. Momentos en el debate por un arte moderno en la Argentina (1880-1960). Buenos Aires: Ediciones del Jilguero, 1998.

${ }^{16}$ Diana Wechsler describe la consolidación de distintos grupos de artistas cuya mera emergencia pone en cuestión al arte tradicional. Ver: WECHSLER, D. Impacto y matices de la modernidad en los márgenes. Las artes plásticas entre 1920 y 1945. In: BURUCÚA, J. E. Nueva Historia Argentina. Arte, sociedad y política. Buenos Aires: Editorial Sudamericana, 1999. Tomo I.

Revista Eletrônica da ANPHLAC, n.11, p. 76-104, jul./dez. 2011. http://revista.anphlac.org.br/index.php/revista 
Respecto a estas discusiones en torno a la idea de nación nos han sido de gran utilidad las reflexiones de Carlos Altamirano y Beatriz Sarlo, quienes plantean la existencia de una línea de continuidad entre los debates sobre la identidad nacional en el campo intelectual del Centenario y las “cristalizaciones ideológicas” que servirán de supuesto a los ataques del ala derecha del nacionalismo a los valores políticos y culturales del liberalismo a fines del '20 y principios del ' 30 . Los autores observan cómo, entre los círculos literarios y políticos, se gesta una reacción nacionalista tendiente a refundar un mito de orígenes con apoyo en el hispanismo — en respuesta al avance de la política de masas. ${ }^{17}$ Según lo plantean, la legitimidad simbólica que se forjan estos intelectuales descansa en el acto de arrogarse el papel de tutores culturales; en tanto conductores de la reacción nacionalista se proponen como los responsables de contrarrestar lo que perciben como efectos perniciosos de una modernización que tiende a la disolución nacional y moral. En cierta medida podríamos ver en Nativa la plasmación de esta reacción en las páginas de una revista cultural. Basta observar aleatoriamente algunas de sus páginas para encontrarse con elocuentes expresiones alusivas al rol central de la revista en la actualidad de la cultura patria y su poder para definir qué es lo que se incluye en ella: para ello no es si quiera necesaria una fina lectura entrelíneas sino que basta que observar las selecciones iconográficas que marcan el ritmo visual de Nativa o los expresivos recuadros que conminan al lector a cumplir con su deber de argentino. El "Siluetas Nacionalistas" Juan Pablo Güemes escribe:

Necesitamos el advenimiento de mentes vigorosas, de hombres columnas, tanto en las artes como en la ciencia, en las letras como en la sociología, para cimentar esta civilización de extremo occidentes, como ha de llamarse la nuestra, la americana. Pero para que esos hombres lleguen, es preciso hacerles ambiente, tenemos el deber de augurarlos, de auspiciarlos y esto es lo que estamos haciendo $[\ldots] .^{18}$

\footnotetext{
${ }^{17}$ ALTAMIRANO, C.; SARLO, B. La Argentina del Centenario: campo intelectual, vida literaria y temas ideológicos. In: ALTAMIRANO, C.; SARLO, B. Ensayos Argentinos. De Sarmiento a la vanguardia. Buenos Aires: Ariel, 1997.

${ }^{18}$ GÜEMES, J. P. Siluetas Nacionalistas. Nativa, n. 57, sept. 1928.
}

Revista Eletrônica da ANPHLAC, n.11, p. 76-104, jul./dez. 2011. http://revista.anphlac.org.br/index.php/revista 
Como mencionamos arriba Nativa asume el rol de definir quiénes forman parte del panteón de artistas nacionales - entre ellos se destacan, Callery, A. Güiraldes, Gramajo Gutiérrez, Ripamonte, etc. - y quiénes quedan afuera, de acuerdo a su contribución al refuerzo de la tradición. Tutores culturales o intelectuales orgánicos, nacionalistas en sentido estricto ${ }^{19}$ que, si bien no siempre lo declaran explícitamente, observan un accionar orientado a conducir la defensa del nacionalismo y la tradición contra los embates del cosmopolitismo y la modernización, que cooptan la disputas ideológicas e institucionales que se desarrollan en el campo intelectual. Para estudiar la manera en que construyen la legitimidad discursiva e iconográfica sobre la que montan su intervención en el campo intelectual nos valdremos de dos nociones como matriz para abordar este problema: formaciones discursivas y comunidad discursiva.

Como en el XIX, para este sector de la clase dirigente la solución a la crisis identitaria parece radicar en la afirmación de la nación y en el refuerzo de los cimientos de la tradición patria - los aportes culturales, la literatura y el arte son constituidas en pilares e incluso en las armas fundamentales para dicha empresa. Lo novedoso de la década del 20 yacerá en que ya no se trata de contender con lo que se percibe como un fenómeno inorgánico producto del arribo de variadas tradiciones nacionales ajenas a la propia sino de luchar contra la búsqueda del establecimiento de identidades alternativas a la supuestamente aceptada por todos. ${ }^{20} \mathrm{El}$ análisis de la manera en que estas preocupaciones se trasladan a la refundación de un mito de orígenes y el modo en que el activismo del nacionalismo telúrico que vemos expresado en Nativa pueden ser enriquecidos si tomamos el concepto de Foucault de "formaciones discursivas" o dispositivos discursivos. Este concepto nos permite comprender cómo se elabora una respuesta en el campo de las representaciones frente a un fenómeno nuevo que irrumpe en el devenir histórico y cómo se suele recurrir a dispositivos preexistentes para darle una respuesta: en nuestro caso al criollismo que le valdrá la acusación de ingenuo a este nacionalismo. Foucault entiende por formaciones discursivas a la matriz ideológica a partir de la que se ponen en juego

\footnotetext{
${ }^{19}$ Es decir, antiliberal, antidemocrático y autoritario. Véase: Devoto, op. cit., p. XII.

${ }^{20}$ BERTONI, L. A. Patriotas, cosmopolitas y nacionalistas. La construcción de la nacionalidad argentina a fines del siglo XIX. Buenos Aires: Fondo de Cultura Económica, 2001. p. 1.
}

Revista Eletrônica da ANPHLAC, n.11, p. 76-104, jul./dez. 2011. http://revista.anphlac.org.br/index.php/revista 
determinadas reglas de generación de enunciados y emplea este concepto para estudiar fenómenos de ruptura y discontinuidades en la construcción del conocimiento. ${ }^{21}$ En nuestro caso podríamos entender a Nativa como el dispositivo discursivo que un sector de los intelectuales nacionalistas montan - frente a la percepción de una ruptura y crisis en la manera de designar y representar "lo nacional" - para gestionar las voces que determinan qué es legítimo entender y proyectar como nación y qué no lo es. El caso de Ricardo Rojas es emblemático entre los intelectuales que colaboran con esta empresa y reconocen que la suya es una tarea tanto científica como patriótica. En este aspecto es fundamental tener en cuenta las propuestas estético políticas de Rojas en la segunda mitad del 20, que haciéndose eco de su propia propuesta de promoción de una estética americana ${ }^{22}$ (“[...] un programa integral para que las tradiciones indígenas fuesen aprovechadas como resorte de la emoción estética en el 'vigorizamiento' de nuestra conciencia racial. ${ }^{23}$ ) rescata el valor central del arte como medio para crear conciencia nacional. ${ }^{24} \mathrm{Al}$ constituir una comunidad discursiva, Nativa funciona como plataforma que expresa una de las posibles maneras en que se traba una ligazón entre un proyecto estético y la actualidad política; esta noción es solidaria al de formación discursiva y habilita el estudio de aquellos grupos que administran los discursos; sin perder de vista que el discurso es indisociable de los modos en que se organizan los mismo intelectuales. ${ }^{25}$ Nativa funciona como una comunidad discursiva con dominante

\footnotetext{
${ }^{21}$ FOUCAULT, M. Arqueología del saber. Barcelona: Siglo XXI, 2002.

${ }^{22}$ Véase ROJAS, R. Silabario de la decoración Americana. Buenos Aires: Losada, 1953.

${ }^{23}$ Id., p. 21.

${ }^{24}$ Para una lectura más detenida de la percepción de Rojas de que el arte era el mejor vehículo de la reacción nacionalista, véase PENHOS, M. Nativos en el salón..., p. 115-117. Del propio Rojas se recomienda la lectura de sus textos: Eurindia, El Silabario y Ollantay. Tragedia en los Andes, en los que ofrece un entramado discursivo que serviría de pauta estética a muchos arquitectos y artistas. Véase: Rojas, R. Obras de Ricardo Rojas. Buenos Aires: Librería de "La Facultad", 1922, Tomos I, IV y VII. También se recomienda la lectura de la ponencia de M. Alba Bovisio: BOVISIO, M. Alba, Universalismo y americanismo en el Silabario de la Decoración Americana de Ricardo Rojas. In: TERCERAS JORNADAS DE ESTUDIOS E INVESTIGACIONES, 2000, Buenos Aires: Instituto de Teoría e Historia del Arte "Julio E. Payró", Facultad de Filosofía y Letras (UBA), 2000. CD-ROM.

${ }^{25}$ El concepto de comunidad discursiva en este caso nos permite ajustar nuestra mirada sobre la manera en que una revista puede operar en la esfera pública y alcanzar cierta injerencia en la construcción de sentido común a largo plazo. De ahí, que para los fines de nuestro trabajo sea más útil que el empleo del concepto de campo intelectual de Bourdieu que nos derivaría a un tema relacionado pero no central a nuestro estudio, en particular las relaciones de fuerzas entre los agentes del campo. Una aproximación a una definición de comunidad discursiva es provista por D. Maingueneau, quien propone a las comunidades discursiva como modos de organización de los hombres y sus discursos deudores de una "[...] identidad marcada por saberes de conocimiento y ciencia en los que sus miembros se reconocen y de los que dan fe los discursos circulantes
}

Revista Eletrônica da ANPHLAC, n.11, p. 76-104, jul./dez. 2011. http://revista.anphlac.org.br/index.php/revista 
ideológica, es decir, como productora de valores, opiniones y creencias. Este concepto facilita, de este modo, el abordaje de esta publicación en su complejidad como escenario desde el que son irradiados los dispositivos que se despliegan para intervenir en el haz de reglas discursivas y simbólicas que permiten que, hasta entonces, la patria connote un significado determinado y que a partir de dicha intervención cambie su referente. ${ }^{26} \mathrm{El}$ concierto de imágenes, el recorte editorial compuesto por intervenciones, reflexiones artísticas y culturales que traducen una postura respecto al arte y la historia son la galaxia de dispositivos que constituyen el engranaje de esta operación patriótica; en otras palabras, los instrumentos para la legitimación de la existencia de la nación Argentina y evidencia de la nacionalidad.

De acuerdo a Falcón los planteos revulsivos de la derecha conservadora y del nacionalismo autoritario alcanzarán su cenit con la reelección de H. Yrigoyen en 1928. Entre este año y 1930 se daría, según este autor, un período preparatorio para la consolidación del peso intelectual y político de los sectores potencial o efectivamente antidemocráticos. ${ }^{27}$ Siguiendo esta hipótesis hemos tomado los números de la revista que son publicados entre 1928 y 1930 como una suerte de observatorio para analizar una de las variantes en la conformación de dicho campo nacionalista. Como ya hemos señalado, Nativa en tanto comunidad discursiva habría de incidir en la reelaboración de un mito de orígenes sostenido en un corpus de ideas que se apoya, con distinta intensidad, en la formación discursiva de un tradicionalismo nostálgico y en un pensamiento reaccionario o antiliberal. Su apuesta consiste en armonizar dos posturas contradictorias, inherentes a su rechazo de la modernidad: por una parte, contribuir al fortalecimiento y crecimiento nacional y, por la otra, poner freno al proceso de hibridación espiritual y cultural derivado de la cuestión inmigratoria. El eje que articula orgánicamente este desafío yace en el ejercicio de demostrar la existencia de una esencia en tanto cimiento inmutable a la identidad nacional, un concierto de virtudes primigenias de la argentinidad que puede que

en el grupo social; esta comunidad es portadora de los juicios y por lo tanto formadora de opiniones". CHARAUdEAU, P.; MAINGUENEAU, D. Diccionario de análisis del discurso. Buenos Aires; Madrid: Amorrortu, p. 102-3.

${ }^{26}$ FOUCAULT, M. Arqueología del saber. Barcelona: Siglo XXI, 2002. p.122-7.

${ }^{27}$ FALCÓN, op. cit., p. 345.

Revista Eletrônica da ANPHLAC, n.11, p. 76-104, jul./dez. 2011. http://revista.anphlac.org.br/index.php/revista 
sean desoídas o eludidas temporalmente, pero no modificadas por el devenir de la historia. Su intervención, es funcional a despojar al mito de orígenes de los vestigios interpretativos que le habría impreso la Generación del 80; para ello será fundamental una operación que convocara a una recuperación del lazo primero entre el espíritu de la tierra y el espíritu del pueblo. Nativa plasma esta búsqueda desde un inicio. Cada número tiene por eje la referencia a uno de los rincones del país, la portada ofrece la reproducción de una pintura de una artista argentino [con la idea de que esta pueda ser utilizada como lámina para enmarcar $]^{28}$ y la portada interior exhibe fotografías o ilustraciones vinculadas a la región que será reseñada al interior de la revista (Anexo de imágenes I y II). En otras palabras, las contradicciones que se les presentan a estos nacionalistas quedan resueltas al tiempo que veladas en la manera en que se valen de un discurso plástico en tanto soporte de su posicionamiento político. Otro de los recursos discursivos - y signos de su falta de ingenuidad - que más llama la atención al recorrer las páginas de esta revista son los vacios, las omisiones y la sordina frente a todo lo que pudiera poner en cuestión a la supuesta esencia nacional que sirve de soporte a su proyecto cultural y estético. La estrategia no consiste en contender abiertamente sino, por el contrario, en ocluir y velar la existencia del otro. Por un lado, se observa todo un ejercicio de montaje de una realidad cultural que da por sentados una serie de argumentos que echan por tierra las características propias del paradigma de la figura del artista y del arte de vanguardia que se van consolidando para la década del 20 - ambos signos de una modernización creciente y de las influencias foráneas que contaminan al ser nacional. Por el otro, cuando acusan recibo del debate de lo nacional en el arte lo hacen sesgadamente con la pretensión de elaborar un corpus visual en el que queden sino resueltas al menos veladas las contradicciones entre nacionalismo y modernización. Las contribuciones a la crítica de arte que ofrece su director, Jorge Díaz Usandivaras, son de por sí elocuentes en este sentido. Ya hemos citado algunos fragmentos de la sección “Arte Argentino" en los que se hace evidente la postura

\footnotetext{
${ }^{28}$ Las láminas que aparecen en la portada son reproducciones de cuadros que la revista adquiere o recibe en donación. Los pintores son siempre argentinos y los motivos representados evocan a la esencia nacional ya sea a través de personajes típicos, paisajes del campo y la ciudad, etc. En uno de los típicos recuadros que aparecen aleatoriamente dispuestos se lee: "Cada portada de Nativa es un cuadros fino, delicado, de nuestros mejores pintores del género criollo. Aprovéchelo usted, colocándolo en un marco para su escritorio o habitación". Nativa, n. 60, dic. 1928.
}

Revista Eletrônica da ANPHLAC, n.11, p. 76-104, jul./dez. 2011. http://revista.anphlac.org.br/index.php/revista 
editorial frente a las vanguardias europeas. Nos queda recuperar la idea que subyace a la crítica según la cual es el arte argentino el que tiene algo para ofrecer al europeo, como si este último hubiera sido víctima de una suerte de regresión a manos de sus vanguardias:

[A raíz de un viaje que Quirós realiza a Europa en marzo de 1929, Usandivaras comenta:] Quirós no va a Europa a pasear su orgullo de consagrado artista [...]. Va, sin poder sofrenar su espíritu patriota, de argentino de verdad, a mostrar sus grandes obras $[\ldots] .^{29}$

Parece que allí [en Europa] se pinta mucho pero que sus muestras carecen de calidad. El Salón de Otoño que visitó Panozzi [el artista sobre el que escribe este artículo] en París, guardaba la enorme cantidad de 5 mil telas carentes de valor en su mayoría. ¿Habrá influido la guerra en este resultado? Casi seguro. [a continuación agrega respecto al arte contemporáneo y a los artistas de vanguardia] [...] los pintores actuales [son] jóvenes y carentes de experiencia $[\ldots]^{30}$

[En otra nota sobre el artista Gaspar Fernandez, ya es más explicito en su rechazo al arte vanguardista] Sus dibujos, oleos, acuarelas de Cholas, Changos, músicos ambulantes, tienen el encanto de la sinceridad, que es mucho para estos tiempos que corremos en donde imperan "Les Fauves" y toda la caterva de adulones de falso arte. ${ }^{31}$

El análisis de la selección iconográfica que se desprende de esta mirada editorial puede explicarse como plasmación de la formación discursiva con la que se articula. Al mismo tiempo nos ha parecido pertinente recuperar el concepto de representaciones proyectuales del que se vale G. Silvestri para ubicar a las imágenes en una batería de problemas que no se limitan a las problemáticas de la estética. ${ }^{32}$ Este concepto alude a la operación o intervención que se realiza sobre una imagen determinada al ser esta apropiada por una comunidad o formación discursiva, ejercicio que permite transformar el sentido del referente y proyectarlo de manera controlada. La iconografía de Nativa cobra un sentido propio al imbricarse con sus el texto. Veamos un ejemplo en el que Usandivaras explica el

\footnotetext{
${ }^{29}$ USANDIVARAS, J. Arte argentino. Nativa, n. 63, marzo 1929.

${ }^{30}$ Id., n. 68, agosto 1929.

${ }^{31}$ Id., n. 70, oct. 1929. Las negritas son mías.

${ }^{32}$ SILVESTRI. Errante en torno a los objetos miro. Relaciones entre las artes y ciencias de descripción territorial en el siglo XIX rioplatense. In: BATTICUORE, Gallo; MYERS (Comp). Resonancias románticas. Ensayos sobre la historia de la cultura argentina (1820-1890). Buenos Aires: Eudeba, 2005. p. 1.
}

Revista Eletrônica da ANPHLAC, n.11, p. 76-104, jul./dez. 2011. http://revista.anphlac.org.br/index.php/revista 
valor de uno de los cuadros seleccionados para su portada en el que la retratada es una vaca:

\begin{abstract}
"La castaña overa", [...] pertenece a la cosecha óptima del conocido pintor Luis I. Aquino. Es una vaca. En esta simple frase puede sintetizarse el alto valor del cuadro, aumento en su calor artístico con el motivo que representa, si hemos de convenir que, pintar en este país una vaca, es hacer más obra que trasladar el lienzo al golfo de Nápoles $[\ldots] .{ }^{33}$
\end{abstract}

El pensar, entonces, a la selección iconográfica como una representación proyectual nos permite insertarla en la serie de elementos de los que se vale la revista para incidir en el proceso de formación de un sentido común en torno a la identidad nacional — estos estarían jugando, como tantos otros dispositivos visuales a los que se recurre en la construcción de una identificación con el "ser argentino"; entre ellos: la vaca, el gaucho, el indio, y el ombú, entre otras, son figuras tan reconocibles como el perfil simplificado del mapa, determinados paisajes como las cataratas, los glaciares, etc. La tierra y el pueblo encarnados en la figura del gaucho, el indio significantes de lo nativo, los retratos de nacionalistas ejemplares que aparecen en las secciones de "Siluetas Nacionalistas" o en "Arte Argentino" - son los elementos vinculantes que subyacen a la estética y a la poiesis de la revista (Anexo de imágenes III). En la selección iconográfica compuesta por reproducciones de obras y fotografías se cubre no solo al pasado cultural del suelo argentino sino también a la naturaleza que evoca a su inmenso territorio (Anexo de imágenes I, II y V). La identidad colectiva se representa no sólo en la historia de su pueblo sino también en la de su naturaleza. Del mismo modo que la vaca puede connotar riqueza y prosperidad, el recurso a lo proyectual hace de la imagen del paisaje una escenificación de una idea de dominio territorial que olvida u omite todo tipo de conflicto en lo que refiere a la conquista del territorio nacional, ya que aparecen plasmados como símbolos ahistóricos de argentinidad. Las portadas exteriores e interiores y todo el concierto iconográfico que sostienen al texto (desde las fotos hasta los pequeños íconos que adornan cada página)

\footnotetext{
${ }^{33}$ USANDIVARAS, J. La portada del presente número. Nativa, n. 57, 30 sept. 1928.
}

Revista Eletrônica da ANPHLAC, n.11, p. 76-104, jul./dez. 2011. http://revista.anphlac.org.br/index.php/revista 
estarían dispuestos en función de un ejercicio de reconstrucción de la memoria patria. Con los portadas de paisajes (rurales o portuarios) Nativa nos inicia en un recorrido por todos los espacios de la naturaleza argentina, con los retratos de animales, indios y gauchos parecería invitarnos a asociar el origen nacional con el origen mismo de la vida. Las figuras del gaucho y el indio conviven en un mismo plano identitario, que revela la misma falta de conflicto que el paisaje en la medida en que son proyectados con el mismo gesto de naturalización esencialista, son también parte del paisaje. (Anexo de imágenes II y VI) Comparten un escenario en el que el paisaje, los animales que simbolizan lo criollo (particularmente la vaca y el caballo) y los hombres portan un mismo valor metafórico. Incluso podríamos hacer una lectura entre líneas a partir de la que interpretásemos que, por su pasado indígena en tanto parte de América, los orígenes de la nación argentina pueden ser rastreados hasta las grandes civilizaciones de la Antigüedad. ${ }^{34}$ La representación de lo nativo recuperada en las páginas de Nativa - y colocada en el panteón ancestral de la patria por medio de un procedimiento en el que el indio aparece como un ser ingenuo y el gaucho como un valeroso patriota- ampliaría esta idea en la medida en que nos remonta a una visión de los orígenes preexistente a la idea liberal que identifica a la civilización con lo europeo. (Anexo de imágenes V y VI) Aquí se puede pensar en una reafirmación de la inversión de la vieja dicotomía liberal de civilización y barbarie. De acuerdo a la hipótesis de Altamirano y Sarlo ${ }^{35}$ el nacionalismo cultural replantea los referentes para la dicotomía de civilización y barbarie quedando lo europeo [personificado en los inmigrantes] del lado de la barbarie y lo rural y lo nativo del lado de la civilización. Nuestra perspectiva de Nativa como comunidad discursiva nos habilita a pensar el modo en que este grupo social participa de la producción de este replanteo y pone en circulación el discurso resultante a través de los dispositivos que venimos describiendo. Una contribución interesante a este

\footnotetext{
34 BOVISIO, M. Alba. Universalismo y americanismo en el Silabario de la Decoración Americana de Ricardo Rojas. In: TERCERAS JORNADAS DE ESTUDIOS E INVESTIGACIONES, 2000, Buenos Aires: Instituto de Teoría e Historia del Arte "Julio E. Payró", Facultad de Filosofía y Letras (UBA), 2000. CDROM. p. 5. El análisis de esta autora nos alcanza una amplia perspectiva de cómo esta concepción se liga a la promoción de una estética que combina ciencia y arte para destacar las bondades de un mestizaje hispanoindígena en la obra de Ricardo Rojas. Restituir lo subrayado en amarillo

35 ALTAMIRANO, C.; SARLO, B. La Argentina del Centenario: campo intelectual, vida literaria y temas ideológicos. In: ALTAMIRANO, C.; SARLO, B. Ensayos Argentinos. De Sarmiento a la vanguardia. Buenos Aires: Ariel, 1997.
}

Revista Eletrônica da ANPHLAC, n.11, p. 76-104, jul./dez. 2011. http://revista.anphlac.org.br/index.php/revista 
tipo de reflexiones es la de Marta Penhos, quien amplía este concepto al analizar la relación entre política, identidad y estética en los textos de Ricardo Rojas. ${ }^{36} \mathrm{Su}$ aporte es fundamental para nuestro estudio en la medida en que sugiere que el fenómeno que está en juego detrás de esta operación discursiva y simbólica es el de la incorporación del gaucho/ indio al panteón de lo nacional en tanto "nativo" y la identificación del "otro terrible" con la figura de los inmigrantes. En este ejercicio simbólico tanto el indio como el gaucho desaparecen de la realidad así como la dimensión conflictiva que se les atribuye en el imaginario liberal, en la medida en que al ser incorporados al panteón son naturalizados y canonizados; al despojarlos de su carácter histórico, quedan cristalizados como las fronteras territoriales en el paisaje. El propio Rojas realiza una contribución a la revista a raíz de su $5^{\circ}$ aniversario en diciembre de 1928. Escribe una carta en la que responde agradecido que lo tuvieran en cuenta como colaborador y felicita el emprendimiento patriótico, pero lo más rico de esta carta yace en una serie de críticas que hará a la revista y observaciones que estarían poniendo sobre el tapete un debate que discurre al interior del nacionalismo cultural; entre quienes promueven un nacionalismo más integracionista (entre ellos Rojas) y quienes lo rechazan [cabe recordar que Rojas es enviado a prisión en los 30]. A continuación reproduciremos algunas partes de la carta:

[...] algunas advertencias. Nativa que es ya un hermoso repertorio sobre la vida del indio y del gaucho en su paisaje originario, debe ser algo más: para ello convendría que al acervo de sus documentos [...] agregaran Ustedes la visión de los conquistadores, y sus viejas ciudades, de los inmigrantes y sus siembras progresivas, del criollo actual [...]. Vibran en su revista la emoción del pasado y la conciencia del presente, pero conviene agregar a esa guitarra criolla una cuerda: el ideal del porvenir [...]. El criollismo ingenuo es una generosa fuente estética, pero lo considero insuficiente como programa civil [...]. La vida no puede retornar a sus fuentes [...] Busquemos en lo nativo de ayer, gérmenes de belleza y estímulos de acción para lo nativo de mañana. ${ }^{37}$

Esta naturalización, esta dilución del conflicto de lo nativo como un problema vivo y su construcción como un elemento del paisaje o del pasado, que cobra forma en algunas de las obras de Rojas que ya hemos mencionado, aparecen en la crítica que Rojas hace a la

\footnotetext{
${ }^{36}$ PENHOS, M. Nativos en el Salón. Artes plásticas e identidad en la primera mitad del siglo XX. In: PENHOS, M.; WECHSLER, D. (Coordinadoras). Tras los pasos de la norma. Salones Nacionales de Bellas Artes (1911-1989). Buenos Aires: Ediciones del Jilguero [Archivos del CAIA], 1999. p.140-1.

${ }^{37}$ ROJAS, R. De Ricardo Rojas. Especial para Nativa en su 5ªniversario. Nativa, dic. 1928.
}

Revista Eletrônica da ANPHLAC, n.11, p. 76-104, jul./dez. 2011. http://revista.anphlac.org.br/index.php/revista 
revista, como signo de una estetización de la empresa patriótica y, por ende, como una suerte de traba para la trascendencia del criollismo propuesto en un programa político. Consideramos que otra manera de leer esta aparente ingenuidad consiste en decodificarla como, en términos de Foucault, una respuesta que evoca lo ya conocido por la urgencia impone la sensación de una identidad nacional en crisis. Éste podría ser entendido como un ejercicio que habilita el movimiento por medio del que se elude retrospectivamente (y con éxito) la representación nacional instalada por años de tradición liberal. Para la crítica de Rojas no se ofrece explícitamente una respuesta, pero en cierto modo se acusa recibo con el gesto de no dejar de publicarla. Sin embargo, un año después en la editorial por el $6^{\circ}$ aniversario apuntan a reforzar la idea de misión criolla y patriótica, señalando:

[Nativa] Se fundó para realizar obra de argentinidad y patriótica, en medio de tanto atrevido periodismo estúpido que tenernos que tolerar bondadosamente y ha cumplido ampliamente su programa a base de una labor silenciosa pero intensa [...] los numerosos amigos que siempre nos han alentado con su colaboración de índole nacionalista [...] son la mejor garantía y contralor de nuestro recto camino. $^{38}$

La nota continúa insistiendo en el carácter heroico de esta empresa editorial y, significativamente, podemos advertir ciertos ecos de la advertencia de Rojas ya que se incorpora la preocupación e intención de profundizar sobre los problemas sociales a los que los gobiernos, hasta entonces, no habrían dado respuesta. Hasta entonces la solicitud de una mayor intervención del gobierno solo había sido explicitada en referencia a la necesidad de que éste subsidiara a los artistas que contribuían a la construcción y consolidación de un sentir nacionalista. Finalmente, nos cabe un comentario final sobre algo que nos pareció sumamente curioso. El número que se publica a fines de septiembre del 30 se limita a mostrar una foto del General Uriburu, vestido en uniforme de gala, en la portada interior de la revista. Una vez más la imagen es el recurso para dar cuenta elocuentemente de la postura editorial de la revista, porque en lo que hace a palabras no encontramos afirmación

\footnotetext{
${ }^{38}$ S/F. Notas. Nativa, n. 72, dic. 1929.
}

Revista Eletrônica da ANPHLAC, n.11, p. 76-104, jul./dez. 2011. http://revista.anphlac.org.br/index.php/revista 
explícita de una apoyo sino la reafirmación de la “[...] eficaz labor patriótica y nacionalista que siempre hemos realizado". 39

\section{Observaciones finales}

En Nativa pareceríamos habernos topado con la imbricación de un proyecto político y uno cultural fusionados a partir de una propuesta estética y poética de por sí elocuente. Nuestra hipótesis es que al constituirse en expresión de dicha fusión, en tanto soporte de su mensaje, las series iconográficas y los artículo que las acompañan revelan y plasman lo que sería la resolución estética de una preocupación política por resignificar el sentido de lo nacional y desligarlo de la tradición liberal. La selección de imágenes está, aparentemente, ligada a la búsqueda de recuperar una tradición anterior a la impuesta por el ideario liberal que se pretende combatir. En esta operación de asociación de política y arte, aparece la naturaleza como elemento clave a la hora de redefinir un mito de orígenes. La promoción de los artistas y el arte "nacionalistas" son percibidos por este sector de la clase dirigente como instrumentos o soportes paran mostrar a los ciudadanos y al resto del mundo de qué se trata ser argentino, entre otras cosas.

Observar la particularidad de la selección iconográfica a partir del concepto de representación proyectual nos ha facilitado la tarea a la hora de pensar cómo esta operación habilita a las imágenes a adquirir un carácter imperturbable en el tiempo, ejercicio fundamental para un nacionalismo que decodifica la identidad nacional en términos esencialistas y, consecuentemente, ahistóricos. Por un lado, al llevar la fusión a un soporte estético sitúa a las imágenes como evidencia de lo bello y lo esencial y deja velada la coyuntura histórica. Por el otro, al ser colocadas en una serie iconográfica al servicio de lo natural, del arte y la esencia nacional, el mensaje no pierde vigencia o caduca. La vigencia del producto de esta empresa de articulación alegórica entre arte y nación hoy se observa como parte de una idea de patria en la que el clisé de que "[...] las bellezas naturales de la Argentina: todos los paisajes y todos los climas [...]" forma parte indispensable de su

\footnotetext{
${ }^{39}$ S/F. Notas. Nativa, n. 81, sept. 1930.
}

Revista Eletrônica da ANPHLAC, n.11, p. 76-104, jul./dez. 2011. http://revista.anphlac.org.br/index.php/revista 
definición al igual que el gaucho y el mate forman parte de nuestros iconos culturales indiscutiblemente. $^{40}$ De este modo, pensadas como representaciones proyectuales las imágenes de la selección plástica cobran mayor elocuencia como un montaje, de clara intencionalidad política, tendiente a convencer a su público de hallarse en el mejor país del mundo. Aún más, es la operación que sirve de sustento a los insistentes llamados del editor a cumplir con la labor de hacer patria. Asimismo, el recuperar este proceso desde la dimensión de las formaciones discursivas nos ha dado la posibilidad de conocer la manera en que son construidas las reglas discursivas que dan lugar a las convenciones sobre las que fueron montadas estas imágenes. Ejercicio valioso si pretendemos trascender la opacidad iconográfica para rescatar su doble valor en tanto documento histórico - es decir, en tanto vestigio y testimonio de una cultura material determinada - ya que nos acerca a la relación de la imagen en la construcción de un sentido histórico que se traduce en la formación de una conciencia nacional a partir de su evocación a elementos de la tradición que forman parte de una memoria discursiva. Más complicado en nuestro caso si consideramos que las imágenes son apropiadas en un contexto en el que se está buscando imprimir cambios en las convenciones. ${ }^{41}$ En este punto observamos entonces la convergencia de la puesta en acto de la construcción discursiva/iconográfica con una rearticulación de los dispositivos que convocan a la memoria colectiva de los argentinos en pos de redefinir las reglas de sentido que connotan a la tradición nacional con un sesgo antiliberal.

A lo largo de este estudio hemos intentado desentrañar el entramado de relaciones que hace de soporte al mensaje que portan los componentes de la secuencia iconográfica seleccionada. Asimismo nos hemos preocupado por observar el modo en que se puede recurrir a la iconografía en la construcción de memoria y cómo se puede disponer de su alcance en el campo visual público como soporte ideológico de una identidad nacional que se busca reconstruir y proyectar. El concepto de formación discursiva nos ha servido para indagar la manera en que un sector del nacionalismo cultural busca promover un nuevo mito de orígenes teniendo por plataforma a una revista cultural y el de representación

\footnotetext{
${ }^{40}$ SILVESTRI, G., op. cit., p. 4.

${ }^{41}$ Para un análisis más profundo sobre el valor de las imágenes en tanto documento histórico y la labor del historiador de las imágenes, véase: BURKE, P. Visto y no visto. Barcelona: Crítica, 2005.
}

Revista Eletrônica da ANPHLAC, n.11, p. 76-104, jul./dez. 2011. http://revista.anphlac.org.br/index.php/revista 
proyectual rastrear la manera en las imágenes funcionan como motor de esta estrategia discursiva. Encontramos en Nativa una estética que reúne a las "evidencias" de una escenificación de la grandeza de nuestra nación. Grandeza que resulta indisociable de la reafirmación del derecho tutelar que la elite criolla se arroga sobre el presente y futuro del país y que se apoya sobre una gran operación discursiva e iconográfica que le permite difundir el "verdadero" enunciado sobre los orígenes, la tradición y el espíritu del país.

Revista Eletrônica da ANPHLAC, n.11, p. 76-104, jul./dez. 2011. http://revista.anphlac.org.br/index.php/revista 


\section{Anexo de imágenes}

\section{Portadas}

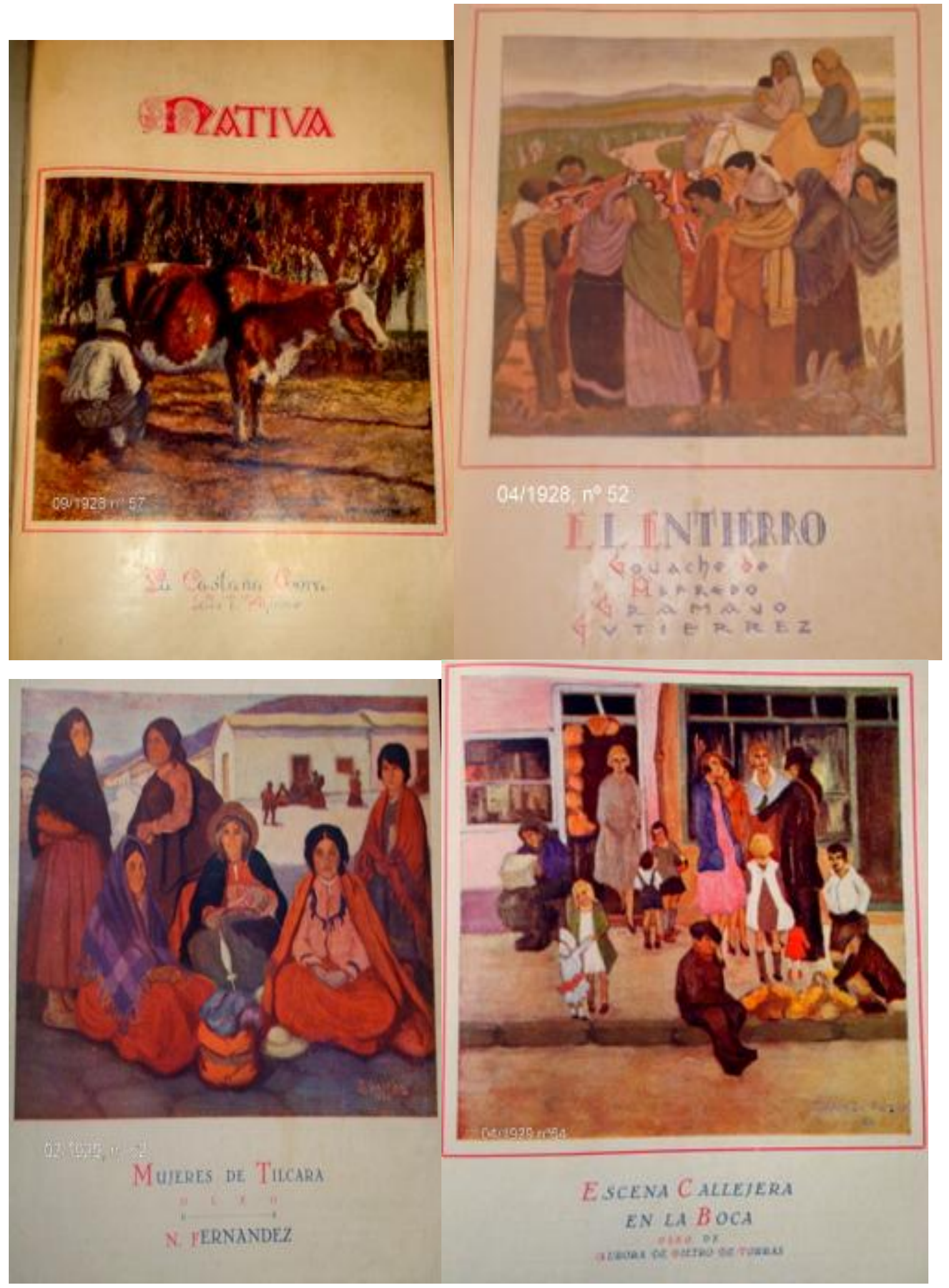

Revista Eletrônica da ANPHLAC, n.11, p. 76-104, jul./dez. 2011. http://revista.anphlac.org.br/index.php/revista 


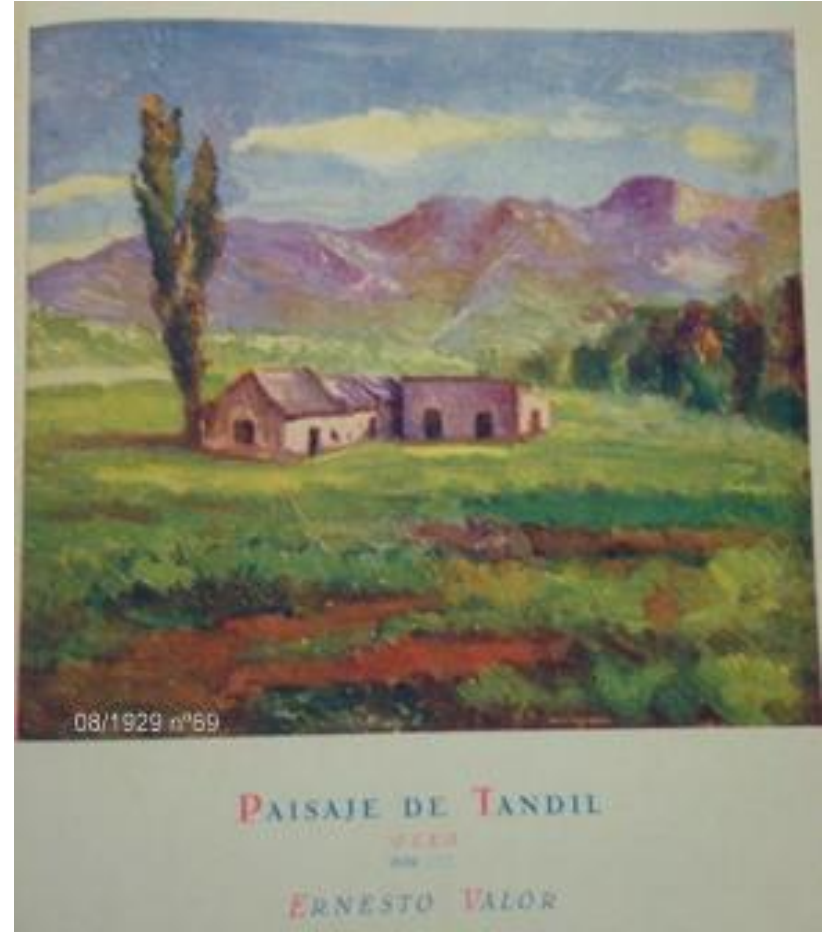

Revista Eletrônica da ANPHLAC, n.11, p. 76-104, jul./dez. 2011. http://revista.anphlac.org.br/index.php/revista 


\section{Portadas interiores}

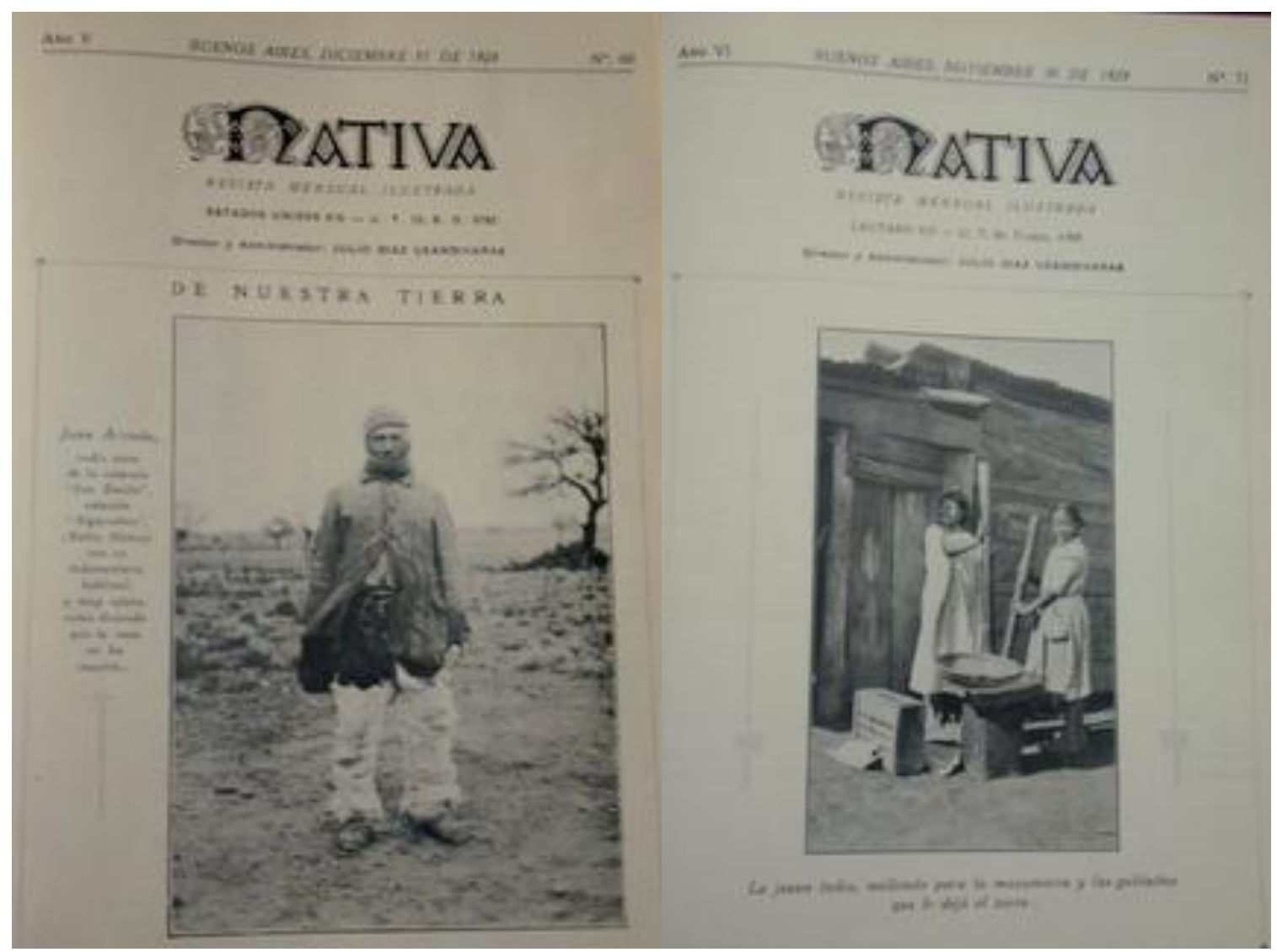

Revista Eletrônica da ANPHLAC, n.11, p. 76-104, jul./dez. 2011. http://revista.anphlac.org.br/index.php/revista 


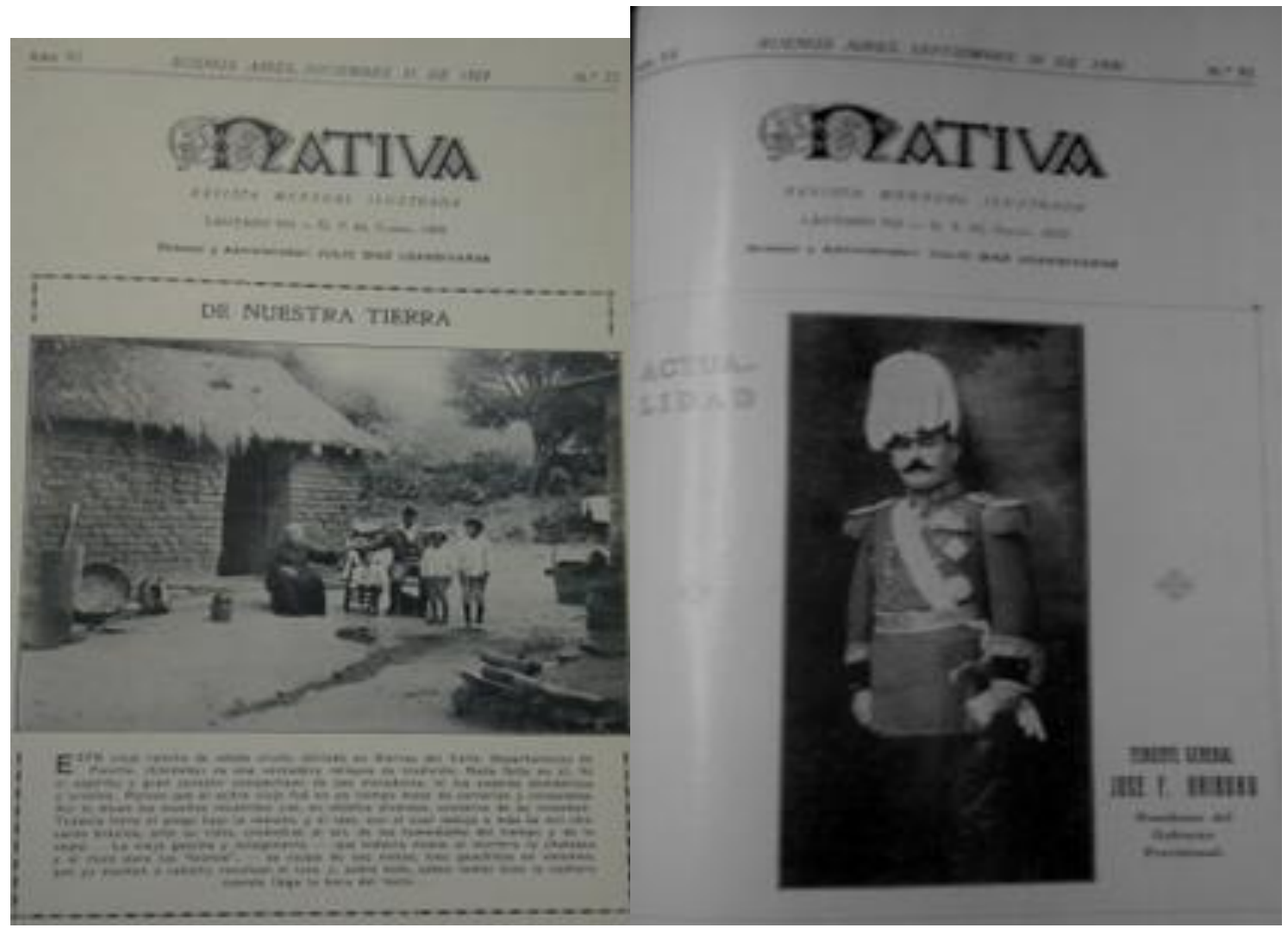

Revista Eletrônica da ANPHLAC, n.11, p. 76-104, jul./dez. 2011. http://revista.anphlac.org.br/index.php/revista 


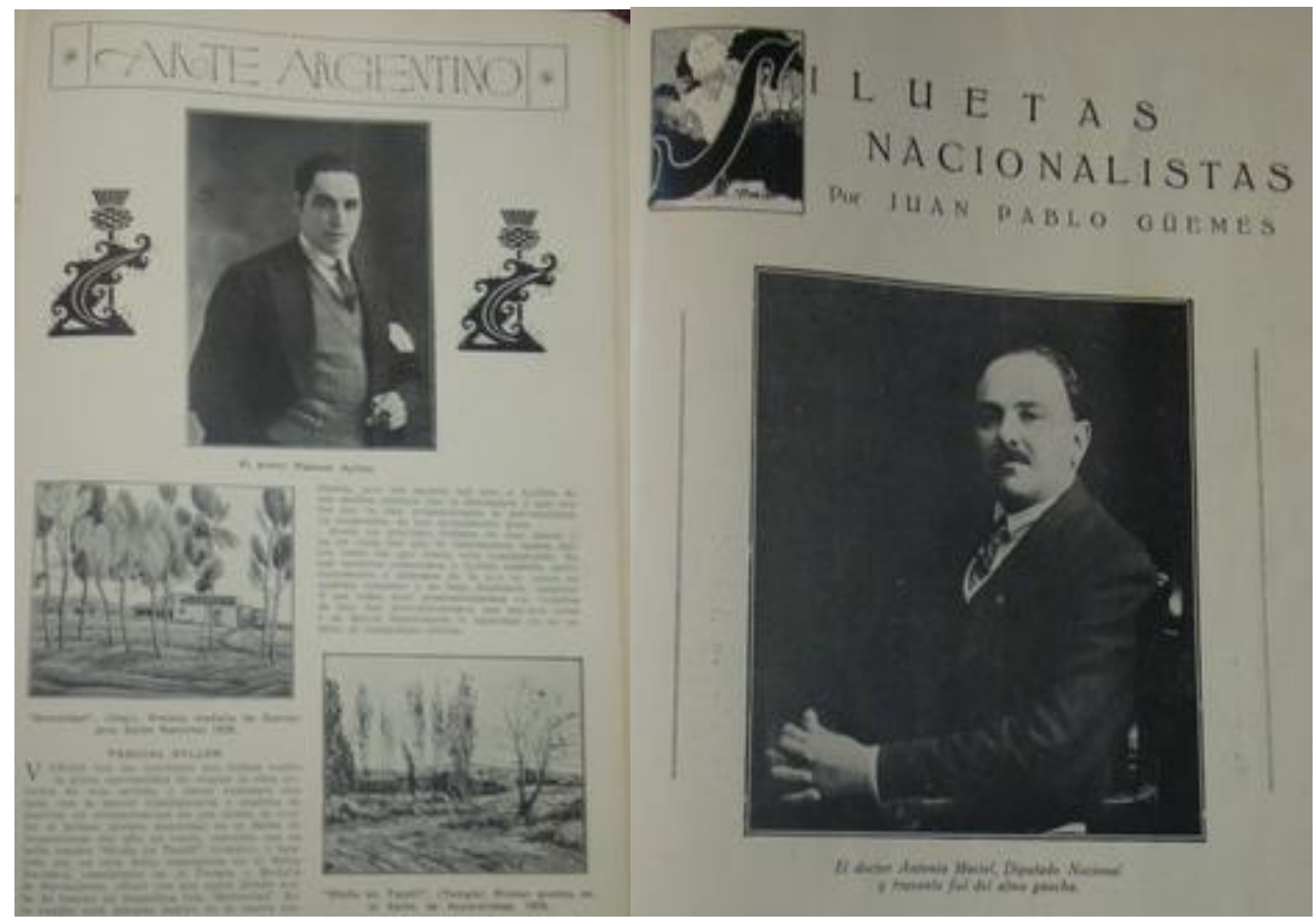

\section{Selección de recuadros}

"HAGA OBRA DE NACIONALISMO Y CONTRIBUYA USTED EL ENGRANDECIMEINTO DE LA PATRIA: ES UN DEBER DE TODO BUEN ARGENTINO”

“LOS PUEBLOS QUE NO CULTIVAN LA TRADICIÓN DE SU NACIONALIDAD, NO HONRAN NI AMAN A LA PATRIA, NI SON DIGNOS DE SU PASADO GLORIOSO”

"SI, SEÑOR, NOSOTROS LE AGRADECEMOS MUCHO A USTED, CON QUE SEA SUSCRIPTOR O LECTOR DE NATIVA. PERO NECESITAMOS QUE SA USTED PROPAGANDISTA DE LA OBRA QUE RELIAZAMOS, RECUERDE QUE LAS GRANDES OBRAS NO DEBEN TENER LIMITACIONES EN EL SENTIDO DEL

Revista Eletrônica da ANPHLAC, n.11, p. 76-104, jul./dez. 2011.

http://revista.anphlac.org.br/index.php/revista 
APOYO. SI QUIERE USTED SENTIRSE VERDADERAMENTE ARGENTINO, LEA NATIVA Y HAGA PROPAGANDA POR ELLA.”

"COLECCIONE USTED NATIVA SI DESEA FORMAR UN VERDADERO PARNASO CRIOLLO PARA SU BIBLIOTECA"

\section{Ejemplos de selección iconográfica}

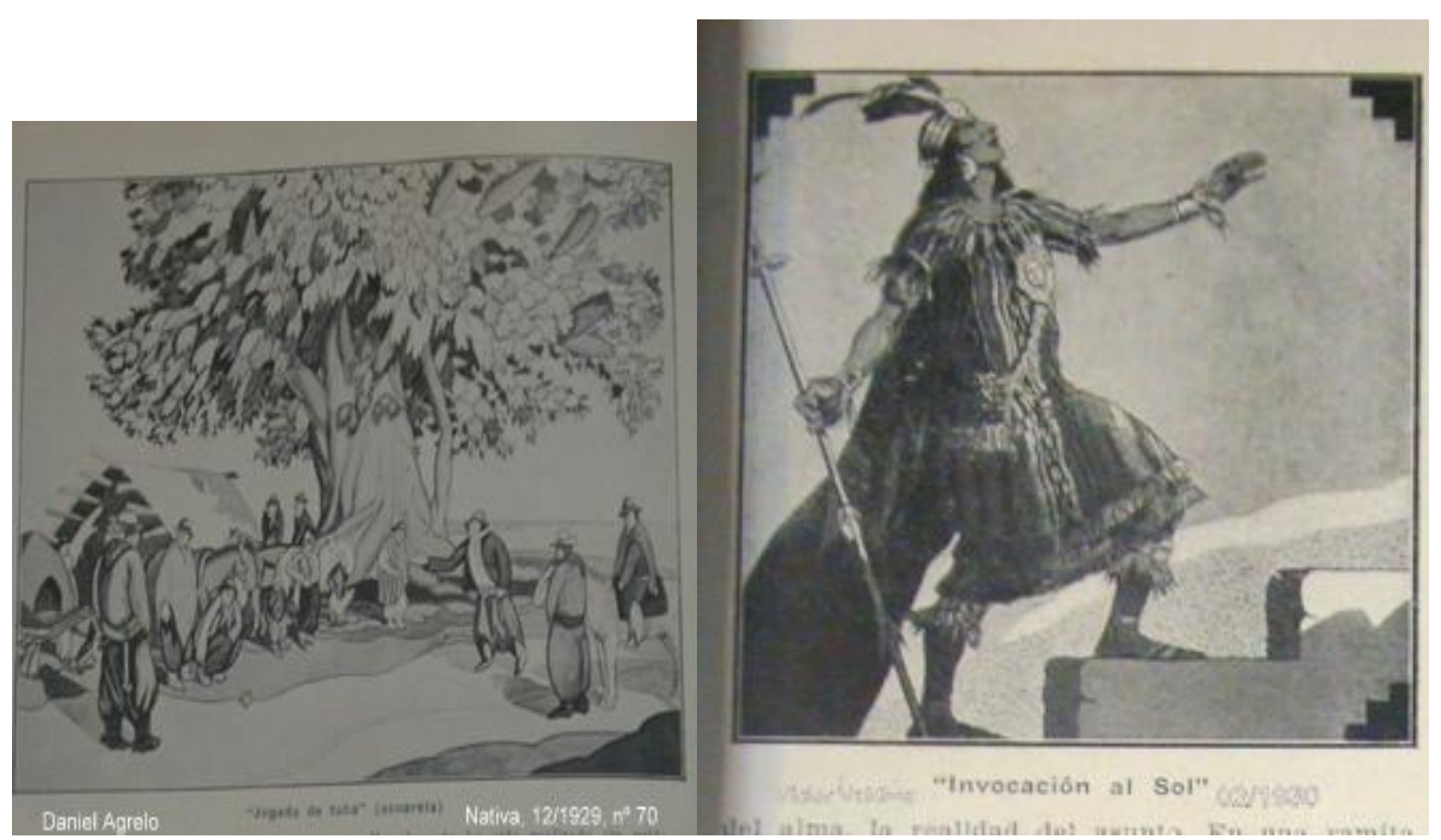

Revista Eletrônica da ANPHLAC, n.11, p. 76-104, jul./dez. 2011. http://revista.anphlac.org.br/index.php/revista 

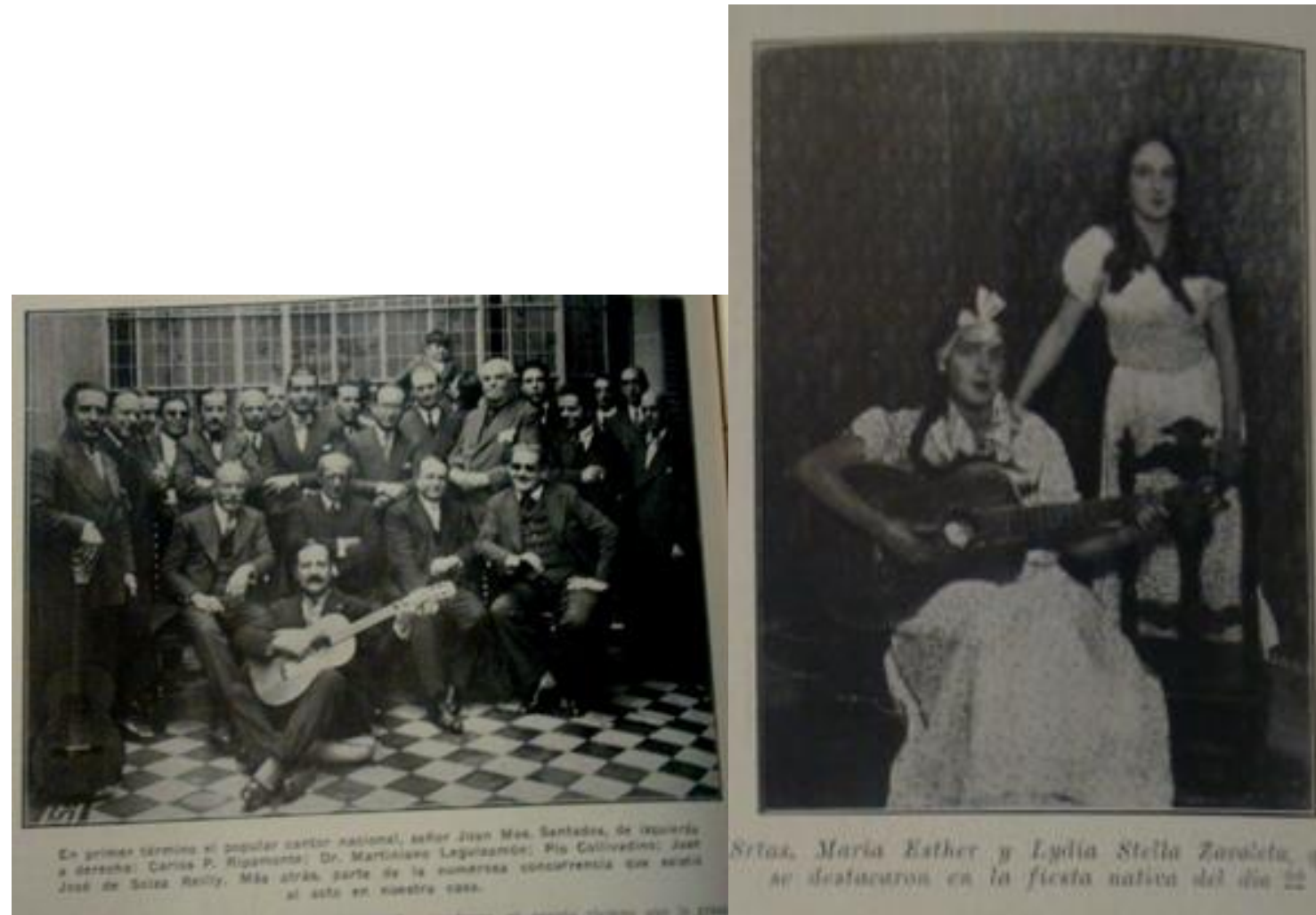

\section{Selección de guardas e íconos que adornan los textos}
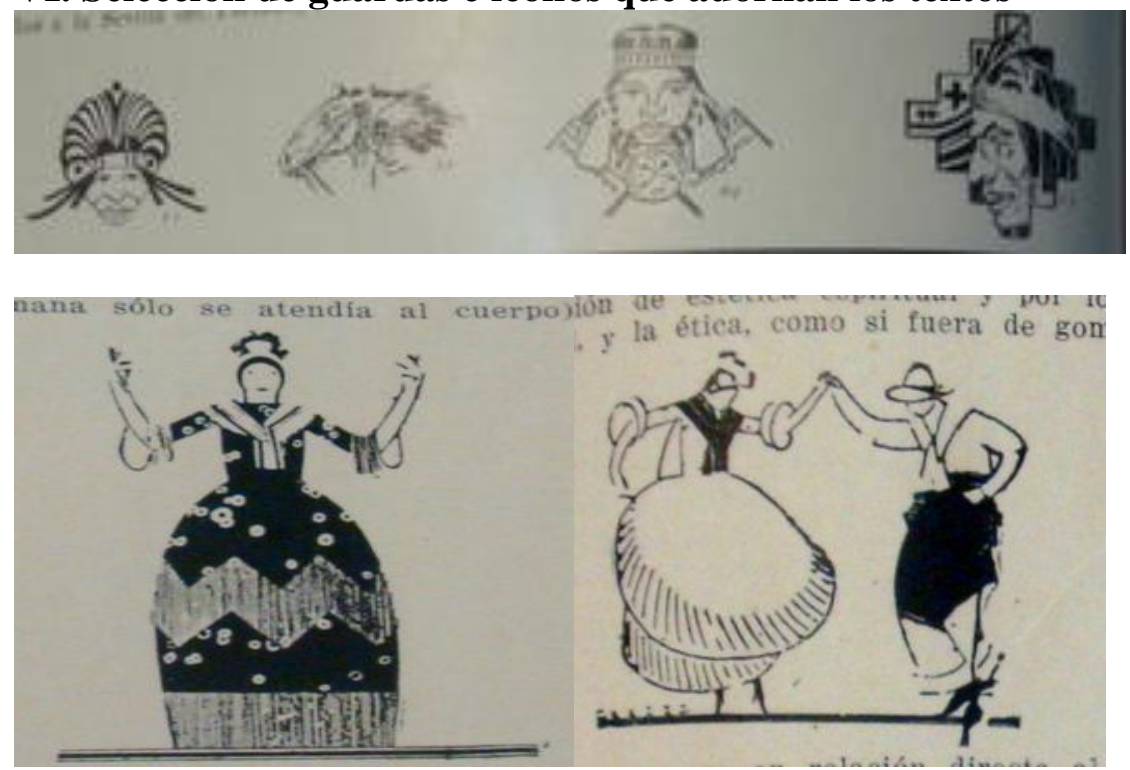

Revista Eletrônica da ANPHLAC, n.11, p. 76-104, jul./dez. 2011. http://revista.anphlac.org.br/index.php/revista 


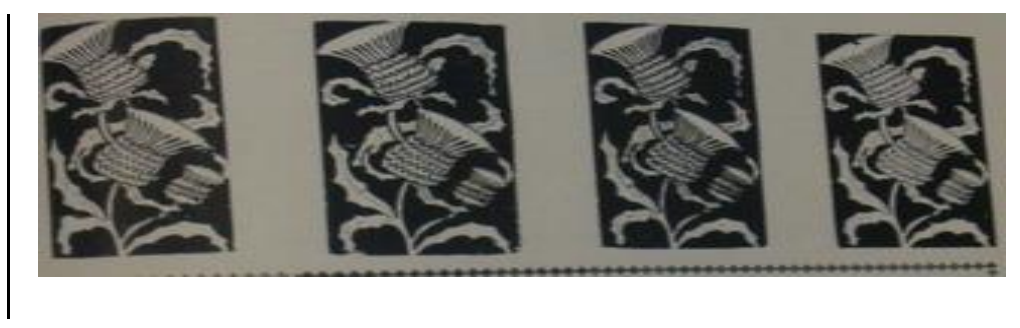

\section{Bibliografía:}

Revistas:

Nativa 1928-1930

Libros:

ALTAMIRANO, C., SARLO, B. "La Argentina del Centenario: campo intelectual, vida literaria y temas ideológicos." In: ALTAMIRANO, C., SARLO, B. Ensayos Argentinos. De Sarmiento a la vanguardia. Buenos Aires, Ariel, 1997.

ALTAMIRANO, C.; SARLO, B. "La Argentina del Centenario: campo intelectual, vida literaria y temas ideológicos." In: ALTAMIRANO, C.; SARLO, B Ensayos argentinos. De Sarmiento a la vanguardia. Buenos Aires: Ariel, 1997.

BERTONI, L.A. Patriotas, cosmopolitas y nacionalistas. La construcción de la nacionalidad argentina a fines del siglo XIX. Buenos Aires: Fondo de Cultura Económica, 2001.

BOVISIO, M. Alba, "Universalismo y americanismo en el Silabario de la Decoración Americana de Ricardo Rojas.” In: TERCERAS JORNADAS DE ESTUDIOS E

INVESTIGACIONES, 3, 2000, Buenos Aires: Instituto de Teoría e Historia del Arte "Julio E. Payró", Facultad de Filosofía y Letras (UBA), 2000. CD-Rom.

BURKE, P. Visto y no visto. Barcelona: Crítica, 2005.

CHARAUDEAU, P.; MAINGUENEAU, D. Diccionario de análisis del discurso. Buenos Aires; Madrid: Amorrortu.

Revista Eletrônica da ANPHLAC, n.11, p. 76-104, jul./dez. 2011.

http://revista.anphlac.org.br/index.php/revista 
DEVOTO, F., Nacionalismo, fascismo y tradicionalismo en la Argentina moderna. Una historia. Buenos Aires: Siglo XXI Editores, 2002.

FALCÓN, R., "Militantes, intelectuales e ideas políticas" In: Falcón, R. (Director), Nueva Historia Argentina. Democracia, Conflicto Social y renovación de ideas. (19161930).Buenos Aires: Editorial Sudamericana, 2000

FOUCAULT, M. Arqueología del saber. Barcelona: Siglo XXI, 2002.

LUGONES, L., El Payador, 1913. Varias ediciones

MUÑOZ, M. A. "Un campo para el arte argentino. Modernidad artística y nacionalismo en torno al Centenario.", In: WECHSLER, D. Desde la otra vereda. Momentos en el debate por un arte moderno en la Argentina (1880-1960). Buenos Aires: Ediciones del Jilguero, 1998.

PENHOS, M. "Nativos en el Salón. Artes plásticas e identidad en la primera mitad del siglo XX”. In: PENHOS, M.; WECHSLER, D. (Coordinadoras). Tras los pasos de la norma.

Salones Nacionales de Bellas Artes (1911-1989). Buenos Aires: Ediciones del Jilguero [Archivos del CAIA], 1999.

ROJAS, R. Obras de Ricardo Rojas. Buenos Aires: Librería de "La Facultad”, 1922, Tomos I, IV y VII.

ROJAS, R. Silabario de la decoración Americana. Buenos Aires: Losada, 1953.

ROMERO, J. L., El desarrollo de las ideas en la sociedad argentina del siglo XX. Buenos Aires: AZ editores, 1998.

SILVESTRI, G. "Errante en torno a los objetos miro. Relaciones entre las artes y ciencias de descripción territorial en el siglo XIX rioplatense." In: BATTICUORE, Gallo; MYERS (Comp). Resonancias Románticas. Ensayos sobre la historia de la cultura argentina (18201890).Buenos Aires: Eudeba, 2005.

WECHSLER, D. "Impacto y matices de la modernidad en los márgenes. Las artes plásticas entre 1920 y 1945" In: BURUCÚA, J.E. Nueva Historia Argentina. Arte, sociedad y política. Buenos Aires: Editorial Sudamericana, 1999. Tomo I

Revista Eletrônica da ANPHLAC, n.11, p. 76-104, jul./dez. 2011. http://revista.anphlac.org.br/index.php/revista 